\title{
ROLE OF N-ACETYLCYSTEINE ON FIBROSIS AND OXIDATIVE STRESS IN CIRRHOTIC RATS
}

\author{
Gustavo PEREIRA-FILH0 ${ }^{1}$, Clarissa FERREIRA ${ }^{2}$, Alex SCHWENGBER ${ }^{1}$, Cláudio MARRONI ${ }^{1,3}$, \\ Cláudio ZETTLER ${ }^{1,4}$ and Norma MARRON| ${ }^{2,5}$
}

\begin{abstract}
Background - Hepatic cirrhosis is the final stage of liver dysfunction, characterized by diffuse fibrosis which is the main response to the liver injury. The inhalatory carbon tetrachloride is an effective experimental model that triggers cirrhosis and allows to obtain histological and physiological modifications similar to the one seen in humans. Aim - To investigate the effects of N-acetylcysteine (NAC) on the fibrosis and oxidative stress in the liver of cirrhotic rats, analyzing liver function tests, lipoperoxidation, activity of glutathione peroxidase enzyme, collagen quantification, histopathology, as well as the nitric oxide role. Methods - The animals were randomly in three experimentals groups: control (CO); cirrhotic (CCl4) and CCl4 + NAC. Evaluate the lipid peroxidation, the glutathione peroxidase enzyme, the collagen and the expression of inducible nitric oxide synthase (iNOS). Results - The cirrhotic group treated with N-acetylcysteine showed trough the histological analysis and collagen quantification lower degrees of fibrosis. This group has also shown less damage to the cellular membranes, less decrease on the glutathione peroxidase levels and less expression of inducible nitric oxide synthase when matched with the cirrhotic group without treatment. Conclusion - N-acetylcysteine seams to offer protection against hepatic fibrosis and oxidative stress in cirrhotic rat livers.
\end{abstract}

HEADINGS - Liver cirrhosis, experimental. Fibrosis. Oxidative stress. Carbon tetrachloride. Acetylcysteine. Rats.

\section{INTRODUCTION}

Cirrhosis is a progressive chronic liver disease which constitutes an irreversible stage of liver dysfunction, characterized by a process of diffuse fibrosis and formation of micro and macro nodules, with distortion of the normal architecture of the hepatic parenchyma. Both the fibrotic cicatrization and the hepatocellular regeneration constitute the main responses of the liver tissue to the numerous aggressions of inflammatory, toxic, metabolic or congestive nature that it suffers ${ }^{(31)}$. Besides the functional and morphologic alterations, studies indicate alterations in the antioxidant defense mechanisms of cirrhotic livers. These alterations, by increasing the generation of reactive oxygen species and free radicals, enhance the lipoperoxidation process, which may make the liver tissue more susceptible to damage. Alterations in the hepatic oxidant/antioxidant mechanisms have been proposed. The imbalance, favoring the oxidants, largely contributes to hepatic necrosis. The oxidative stress resulting from the imbalance of pro-oxidant/antioxidant mechanisms leads to oxidative alterations in the lipids of cell membranes, composed of polyunsaturated fatty acids, which can lead to the loss of functionality through alterations in cell homeostasis ${ }^{(28,40)}$. The chain propagation of lipid peroxidation forms reactive compounds with oxygen or nitrogen, enhancing its damage. This aggression interferes with the cell mechanisms, enzyme mechanisms, genic expression and second messenger mechanisms ${ }^{(40)}$. The oxidative stress generated by various conditions activates the hepatic stellate cells and it has a possible link between the hepatic chronic damage and liver fibrosis, leading to cirrhosis as a final endpoint ${ }^{(43)}$.

A classic example of oxidative damage to the liver tissue is a model of inhalatory carbon tetrachloride $\left(\mathrm{CCl}_{4}\right)^{(15,19,21)}$. This model is effective in triggering fibrosis and in the long run cirrhosis, and allows to obtain histologic and hemodynamic modifications that are characteristic of the liver cirrhosis and portal hypertension seen in humans ${ }^{(19)}$. Its action is based on the potent hepatotoxicity of $\mathrm{CCl}_{4}$, which leads to hepatic damage by means of free radicals formed during its metabolism: trichloromethyl $\left(-\mathrm{CCl}_{3}\right)$ and trichloromethyl peroxyl (-OOCCl). These free radicals, when metabolized by the $\mathrm{p}-450$ cytochrome, generate oxidative stress, which leads to hepatic damage and a subsequently irregular hepatic regeneration (fibrosis) ${ }^{(15,28)}$.

The use of antioxidants can minimize the oxidative stress and contribute to the therapeutic in cirrhotic livers. Among the various antioxidants, $\mathrm{N}$-acetylcysteine (NAC) is a small molecule which, by being freely filterable, has prompt access to the intracellular compartments ${ }^{(8,14)}$. This drug has a diversity of applications, largely because of the chemical properties of the thiol moiety present in its structure. The ability of the reduced thiol moiety to sweep reactive

${ }^{1}$ Federal School of Medical Sciences of Porto Alegre, RS; ${ }^{2}$ Lutheran University of Brazil Canoas, RS; Departments of ${ }^{3}$ Gastroenterology/Hepatology and ${ }^{4}$ Pathology, "Santa Casa" Hospital Complex, Porto Alegre, RS; ${ }^{5}$ Digestive Physiology, Federal University of Rio Grande do Sul, Porto Alegre, RS, Brazil

Correspondence: Dr. Norma Marroni - Rua Jose Kanan Aranha, 102 - 91760-470 - Porto Alegre, RS, Brazil. E-mail: nmarroni@terra.com.br 
oxygen species is well-established with $\mathrm{NAC}^{(1,7)}$. In addition to this marked antioxidant capacity, NAC exerts an indirect protection to the liver by being hydrolyzed into cysteine, thus serving as a substrate for reduced glutathione increasing its levels. With this, it is applicable in intoxication by acetaminophen, as well as in adult respiratory distress syndrome, chronic bronchitis and cystic fibrosis ${ }^{(16)}$

Using a modified experimental model of liver cirrhosis induced by $\mathrm{CCl}_{4}$ inhalation, the present study was designed to evaluate the fibrosis and the oxidative stress in the liver of cirrhotic rats, through the collagen quantification, the histopathologic aspect of the hepatic tissue, the liver function tests, the damage to cell membranes through lipoperoxidation, the activity of enzyme glutathione peroxidase as well as the nitric oxide role in this process.

\section{METHODS}

\section{Animals}

The procedures with the animals complied with the guidelines of the Health Research and Ethics Committee of the Research and Postgraduate Group of the "Hospital de Clínicas de Porto Alegre, RS, Brazil'(13).

Fifteen male Wistar rats (mean weight $=250 \mathrm{~g}$ ) were used. They were obtained from the laboratory animals facility of the Federal University of Rio Grande do Sul and were housed in polypropylene cages, in groups of five, and kept under a $12 \mathrm{~h}$ light/dark cycle and controlled room temperature. The animals were fed with rat chow in a quantity of $16 \mathrm{~g}$ per animal/day (Purina-Nutripal, Porto Alegre, RS, Brazil). The water was given ad libitum.

\section{Groups and treatment}

The animals were divided in 3 groups: I- control; II- cirrhotic; III - cirrhotic + NAC.

NAC (Sigma. St. Louis, MO, USA) was administered i.p. at a dose of $10 \mathrm{mg} / \mathrm{kg} /$ day $^{(42)}$. It was initiated at week 10 th, when histological analyses and liver function tests indicated that the animals were already cirrhotic, and was carried out until the date of sacrifice ${ }^{(6)}$.

\section{Cirrhosis induction}

For enzymatic induction and to shorten the time needed for the development of cirrhosis, phenobarbital $(0.3 \mathrm{~g} / \mathrm{L})$ was added to the animal's drinking water 7 days before the first inhalation and, later, throughout the experiment. The $\mathrm{CCl}_{4}$ group was exposed to the aggressive agent twice a week (mondays and fridays), according to JIMENEZ and CLARIÁ(5), inside an inhalation chamber of $65 \times 26 \times 21 \mathrm{~cm} . \mathrm{CCl}_{4}$ was placed in a glass container (humidifier) attached to an air compressor and released into the chamber at a flow of $1 \mathrm{~L} / \mathrm{min}$. In the first three sessions the length of gas exposure was $30 \mathrm{sec}$ and the animals remained inside the chamber for another $30 \mathrm{sec}$ while the compressor was off (waiting time). In the fourth session, the length of gas administration was increased to 1 minute followed by another minute in waiting mode. Subsequently, the length of gas administration and the permanence period in the chamber were increased by $30 \mathrm{sec}$ every three sessions, up to reaching a peak of 5 min at 16 weeks.

\section{Biochemical analyses}

The animals were sacrificed at week $16^{\text {th }}$. First they were anesthetized with ketamine $(100 \mathrm{mg} / \mathrm{kg})$ and xylasine $(50 \mathrm{mg} / \mathrm{kg})$ i.p.. Then blood was sampled from their retro-ocular sinus for determination of total (TB) and direct bilirubin (DB), aspartate aminotransferase (AST), alanine aminotransferase (ALT), alkaline phosphatase (AP) and albumin (ALB). Serum levels of TB, DB, AST, ALT, AP and ALB were determined by commercial kits. The liver was removed and stored at $-70^{\circ} \mathrm{C}$ for posterior quantification of thiobarbituric acid reactive substances (TBARS), enzymes, collagen, nitrites and nitrates, as well as histology.

\section{Homogenate}

After complete excision of the liver and withdrawal of the material for fixation in formalin, the region corresponding to the medial portion of the right lobe $(1.5 \times 0.5 \times 0.5 \mathrm{~cm})$ was resected for homogenization. The liver fragment, before homogenization, was kept at a temperature of $2^{\circ} \mathrm{C}$ in physiological solution. Nine milliliters of phosphate buffer $(140 \mathrm{mM} \mathrm{KCl}, 20 \mathrm{mM}$ phosphate, $\mathrm{pH}$ 7.4) per gram of tissue was placed into the homogenization tube. The liver was homogenized with Ultra-Turrax (IKAWERK) at a temperature of $2^{\circ} \mathrm{C}$ for $30 \mathrm{~s}$. This homogenate was centrifuged (SORVALL RC-5B Refrigerated Superspeed Centrifuge) at $3.000 \mathrm{rpm}$ for $10 \mathrm{~min}^{(17)}$. The supernatant was transferred by pipette to Eppendorf tubes and the precipitate was discarded. The samples were conditioned at $-70^{\circ} \mathrm{C}$ for later use in the several techniques used.

\section{Proteins}

In this method a bovine albumin solution (SIGMA) was used at a concentration of $1 \mathrm{mg} / \mathrm{mL}$, according to LOWRY et al. ${ }^{(20)}$ The samples were measured in the spectrophotometer at $625 \mathrm{~nm}^{(20)}$, being expressed in $\mathrm{mg} / \mathrm{mL}$, for expression of the values of antioxidant enzymes and TBARS.

\section{TBARS (evaluation of thiobarbituric acid reactive substances)}

The amount of aldehydic products generated by lipid peroxidation was quantified by the thiobarbituric acid reaction using $3 \mathrm{mg}$ of protein per sample. Results were referred as TBARS. The samples were incubated at $90^{\circ} \mathrm{C}$ for $30 \mathrm{~min}$ after adding $500 \mu \mathrm{L}$ of $0,37 \%$ thiobarbituric acid in $15 \%$ trichloroacetic acid, then centrifuged at $4^{\circ} \mathrm{C}$ at $2000 \mathrm{x}$ g for $15 \mathrm{~min}$. Spectrophotometric absorbance was determined in the supernatant a $535 \mathrm{~nm}^{(3)}$.

\section{Glutathione peroxidase}

The activity of antioxidant enzyme glutathione peroxidase was evaluated by the NADPH oxidation rate in the presence of reduced glutathione (GSH) and glutathione reductase (GR). The sodium azide $\left(\mathrm{NaN}_{3}\right)$ is added to inhibit the activity of catalase. Finally, the decrease in NADPH absorbance at $340 \mathrm{~nm}$ was 
measured. The activity of enzyme glutathione peroxidase is expressed as $\eta \mathrm{mol} / \mathrm{min} / \mathrm{mg}$ of $\operatorname{protein}^{(9)}$.

\section{Collagen}

Collagen concentration was determined by measuring the hydroxyproline content in fresh liver sections after acid digestion. It is read at $560 \mathrm{~nm}$ in the spectrophotometer and is expressed as $\mu \mathrm{g} / \mathrm{mg}$ of $\operatorname{protein}^{(33)}$.

\section{Western Blot - iNOS}

Determination of protein iNOS was performed through Western Blot using system Laemmli, 1970. The technique demands homogenization of the liver in lysis buffer $(140 \mathrm{mM} \mathrm{NaCl}, 15 \mathrm{mM}$ EDTA, 10\% glycerol, 20mM Tris; $\mathrm{pH} 8.0$ ) adding a mixture of protease inhibitors (protease inhibitor cocktail tablets; Roche; ref. 1836170). After homogenization it is incubated for $30 \mathrm{~min}$ at $4^{\circ} \mathrm{C}$, subsequently centrifuged for $30 \mathrm{~min}$ at $17,000 \mathrm{xg}$ and $4^{\circ} \mathrm{C}$, and the supernatant is withdrawn at aliquots.

Polyacrylamine gel electrophoresis $(10 \%)$ was performed. The sample was placed into each groove, comparing all the groups at the same gel. After this procedure, proteins were transferred to a nitrocellulose membrane and, after blocking unspecific bindings, it was incubated with anti-iNOS polyclonal antibody obtained from rabbit (NOS2, H-174; Santa Cruz Biotechnology). After incubation with secondary antibody marked with peroxidase, obtained from pig (DAKO), determination was finally performed by chemoluminescence (ECL, RPN2109, Amersham Pharmacia Biotech). Immunoquantification was done by comparing densitometrically the values of control samples with their corresponding ones in each of the other groups considered. The results were expressed relative to the percentage of the control (100\% or 189735 pixels).

\section{Histology}

For the histological examination the material was included in paraffin blocks and subsequently cut into $6 \mu$-thick sections on a rotating microtome. The technique of picrosirius staining was performed, which shows the collagen present in the sample, in order to evaluate the extent of hepatic fibrosis in the samples. The plates were examined under a binocular microscope (Nikon Labophot) at magnifications of 25x, 100x, 200x and 400x.

The degree of fibrosis was assessed according to the score/ scale below:

- The degree of liver fibrosis was determined by the semiquantitative method according to the score system ${ }^{(32)}$.

0: Normal liver with no fibrosis

I: Thick perivenular collagen and few collagen septa

II: Thin septa with incomplete bridges across the portal regions

III: Thin septa and extensive bridges

IV: Thick septa with complete bridges across portal regions and nodular appearance

- Mild degree: compromising of $25 \%$ of portal spaces

- Moderate degree: compromising of $25 \%-75 \%$ of portal spaces

- $\quad$ Severe degree: compromising of over $75 \%$ of portal spaces

\section{Statistical analysis}

The results were expressed as mean + standard error (SEM) of (n) values. ANOVA, followed by Student Newman Keuls, was used for group comparison, and $P<0.05$ was considered as significant. A non-parametric test (Mann-Whitney) was used for the anatomic-pathological analysis.

\section{RESULTS}

\section{Biochemical analysis}

Concerning the markers of liver damage AST and ALT, a significant difference was observed $(P<0.05)$ between the control $(179 / 109 \mathrm{U} / 1)$ and cirrhotic groups had higher plasma levels (465.6/653.2 U/1). The NAC no reduced significantly the increase in transaminase activities in this experiment (Table 1). In the other tests performed, direct bilirubin, total bilirubin, albumin and alkaline phosphatase, this difference was not observed as all the other groups were paired.

TABLE 1. AST, ALT, TBARS, GPx and collagen full data

\begin{tabular}{lccccc}
\hline & $\mathrm{Co}$ & $\mathrm{CCl}_{4}$ & $\mathrm{CCl}_{4}+\mathrm{Nac}_{4}$ & $\mathrm{CCl}_{4} \times \mathrm{Co}$ & $\mathrm{CCl}_{4} \times \mathrm{CCl}_{4}+\mathrm{Nac}$ \\
\hline ALT & $179 \pm 37.38$ & $465.6 \pm 33.6$ & $387.6 \pm 19.9$ & $P<0.05$ & $\mathrm{NS}$ \\
AST & $109 \pm 39.01$ & $653.2 \pm 164.87$ & $570 \pm 113.54$ & $P<0.05$ & $\mathrm{NS}$ \\
TBARS & $0.96 \pm 0.15$ & $2.08 \pm 0.25$ & $1.07 \pm 0.30$ & $P<0.05$ & $P<0.05$ \\
GPx & $397.36 \pm 18.82$ & $164.77 \pm 45.6$ & $318.74 \pm 36.31$ & $P<0.01$ & $P<0.05$ \\
Collagen & $27.99 \pm 5.65$ & $156.73 \pm 37.04$ & $45.23 \pm 16.5$ & $P<0.01$ & $P<0.01$ \\
\hline
\end{tabular}

Co-Control group; $\mathrm{CCl}_{4}$ - cirrhotic group;

$\mathrm{CCl}_{4}+\mathrm{NAC}$ - Cirrhotic group treated with $\mathrm{N}$-acetylcystein

ALT - aspartate aminotransferase; AST - alanine aminotransferase;

GPx-glutathione peroxidase; values are means \pm S.E. $(n=5)$ in each group

\section{Lipid peroxidation}

The analysis of the values obtained by the method of TBARS shows a $54 \%$ increase in lipoperoxidation in the $\mathrm{CCl}_{4}$ group as compared to $\mathrm{CO}$ group. As the $\mathrm{CCl}_{4}$ group is compared to the $\mathrm{CCl}_{4}+\mathrm{NAC}$ group, a decrease of $48.5 \%$ is observed, returning to the levels of the control groups (Table 1 and Figure 1).

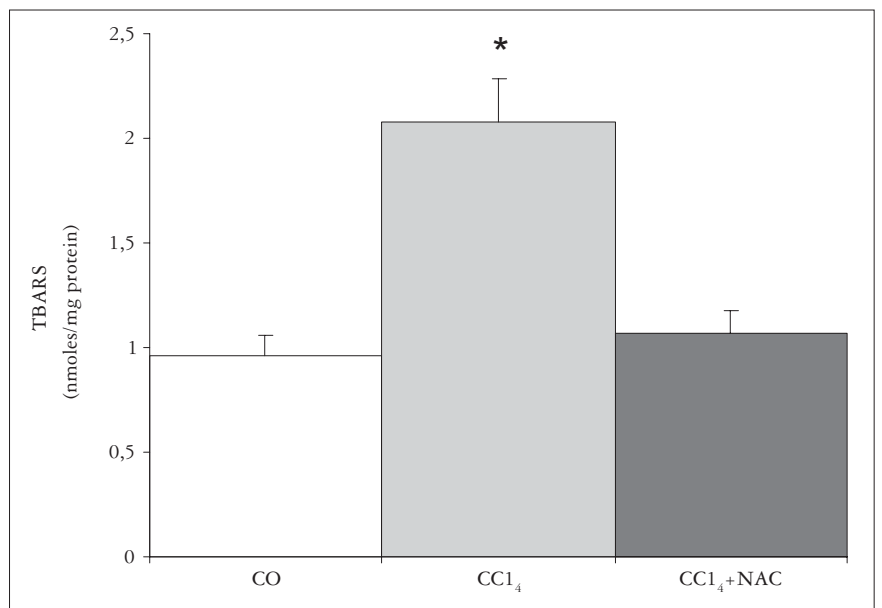

Mean \pm standard error $(n=5)$.
$* P<0.05$ vs control; $\# P<0.05$ vs cirrhotic $C O-$ Control, $\mathrm{CCl}_{4}-$ Cirrhotic, $\mathrm{CCl}_{4}+\mathrm{NAC}-$ Cirrhotic treated with NAC, CO + NAC - Control treated with NAC

FIGURE 1. Effects of carbon tetrachloride inhalation and NAC administration on lipoperoxidation, analyzed by the TBARS method 


\section{Glutathione peroxidase}

Comparing the levels of enzyme glutathione peroxidase, a decrease of $58.5 \%$ in the $\mathrm{CCl}_{4}$ group was observed as compared to the control group. The $\mathrm{CCl}_{4}+\mathrm{NAC}$ group presented a $93 \%$ increase in the levels of this enzyme as compared to the cirrhotic group, levels similar to those of the control animals (Table 1 and Figure 2).

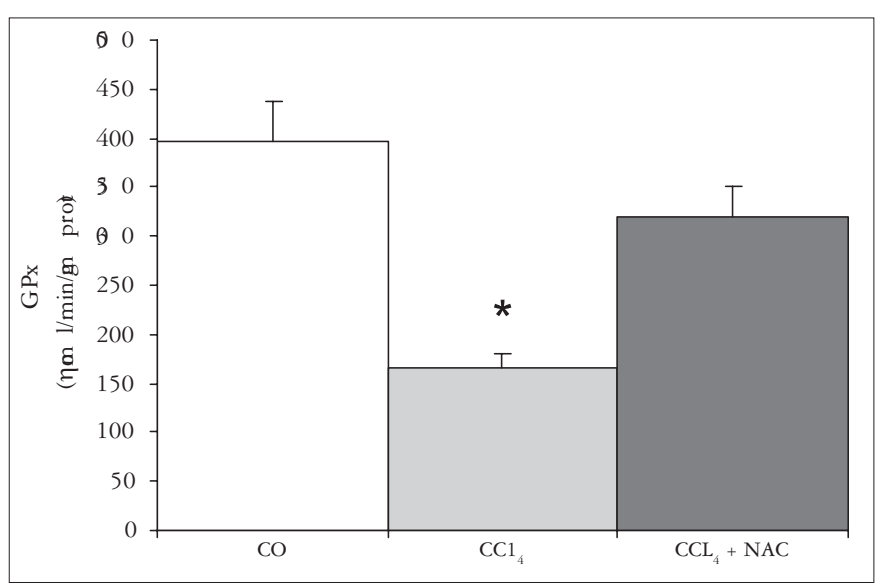

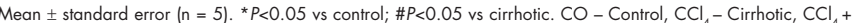
NAC - Cirrhotic treated with NAC, CO + NAC - Control treated with NAC

FIGURE 2. Effects of carbon tetrachloride inhalation and NAC administration on hepatic levels of glutathione peroxidase

\section{Collagen}

Collagen concentration increased 5.6-fold in the cirrhotic group as compared to the control group and only 1.6-fold in the cirrhotic + NAC group, values that were statistically significant (Table 1 and Figure 3)

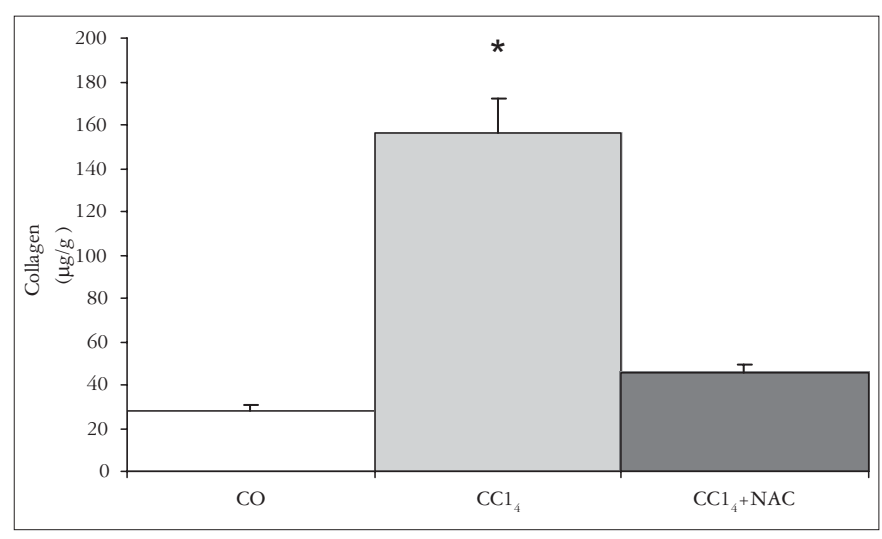

Mean \pm standard error $(n=5)$. ${ }^{*} P<0.05$ vs control; $\# P<0.05$ vs cirrhotic.

$\mathrm{CO}-$ Control, $\mathrm{CCl}_{4}-$ Cirrhotic, $C \mathrm{Cl}_{4}+\mathrm{NAC}-$ Cirrhotic treated with NAC, $\mathrm{CO}+\mathrm{NAC}-$ Control treated with NAC

FIGURE 3. Effects of carbon tetrachloride inhalation and NAC administration on hepatic collagen build-up

\section{Histology}

The histology of the animals at the 10th week shows installed cirrhosis in the animals of the $\mathrm{CCl}_{4}$ groups, due to the presence of nodular fibrosis. In week 16th animals, cirrhosis becomes more severe in the $\mathrm{CCl}_{4}$ group, while in the $\mathrm{CCl}_{4}+\mathrm{NAC}$ group it regresses to mild or moderate fibrosis, with alterations only in periportal spaces. No histological alterations were seen in control animals (Figure 4 A, B, C, D, E and F).
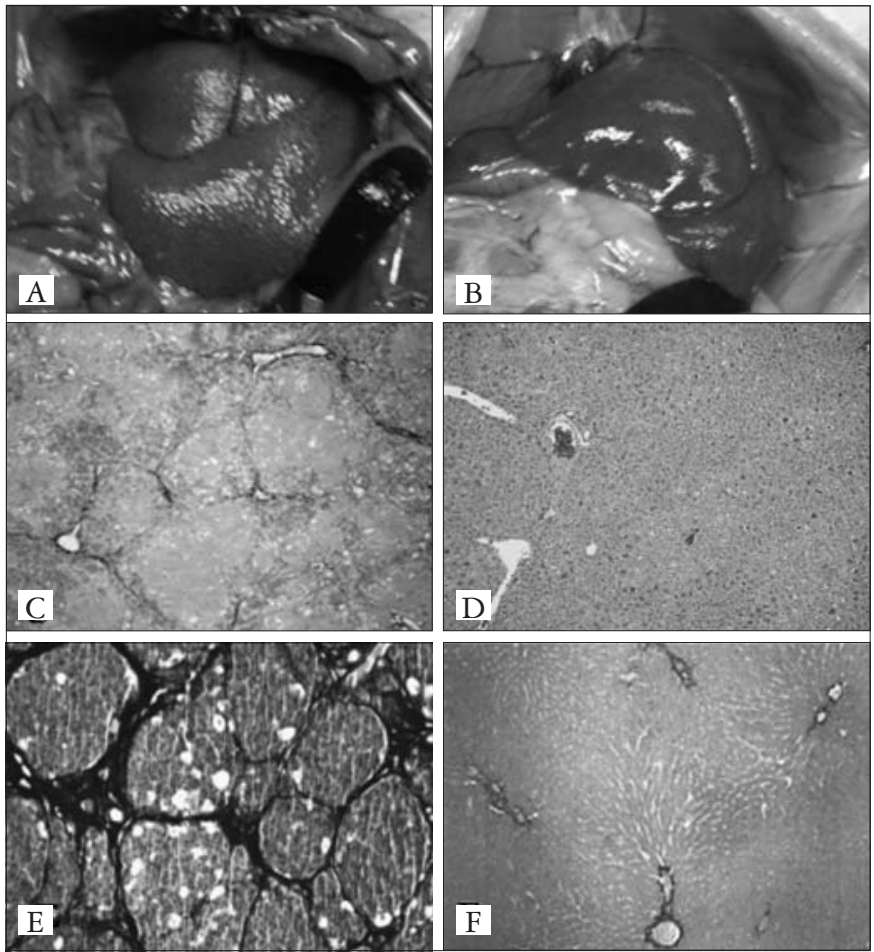

FIGURE 4. A. representative macroscopic view of cirrhotic rat liver; $\mathbf{B}$ representative macroscopic view of cirrhotic rat liver treated with NAC; C. Cirrhotic rat -10 th inhalation week liver section $(40 \mathrm{x})$; D. Control rat liver section $(40 \mathrm{x}) ; \mathrm{E}$. Cirrhotic rat - 16th inhalation week liver section (40x); F. Cirrhotic rat treated with NAC (40x). Picrosirius red staining

\section{Western Blot - iNOS}

The expression of iNOS was elevated in the animals of the cirrhotic group, returning to control levels in NAC- treated animals (Figure $5 \mathrm{~A}$ and $\mathrm{B}$ ).

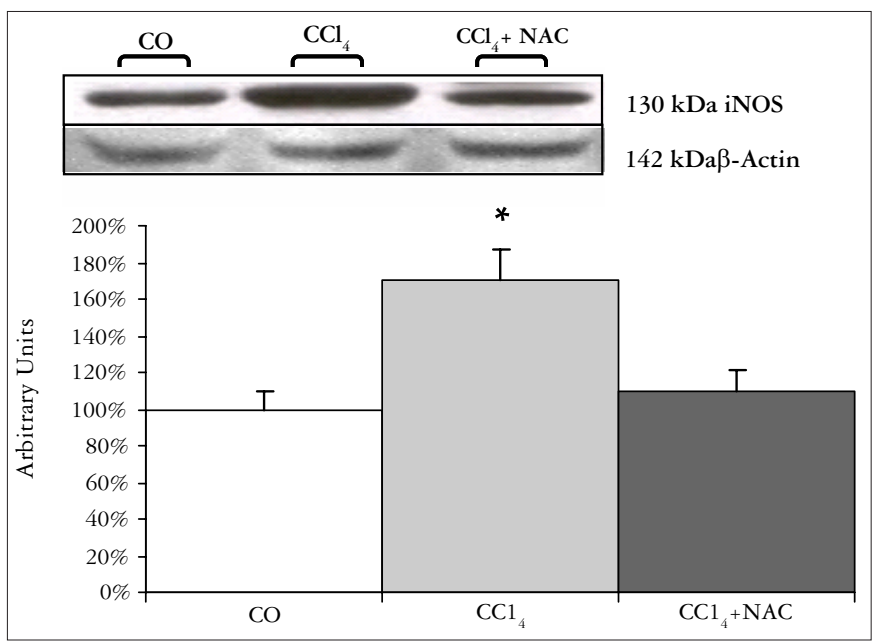

$\mathrm{CO}-$ Control, $\mathrm{CCl}_{4}-$ Cirrhotic, $\mathrm{CCl}_{4}+\mathrm{NAC}-$ Cirrhotic

FIGURE 5. Western blot analysis of iNOS protein in livers from different experimental groups. Total cellular protein was separated on $12 \%$ SDSpolyacrylamide gels and blotted with anti-iNOS antibodies. (A) Shows representative Western blot photographs. (B) Expresses the results in arbitrary units 


\section{DISCUSSION}

Liver cirrhosis induced by $\mathrm{CCl}_{4}$ inhalation is an effective experimental method in which the hepatic lesion originates from free radical formation. The model used in this work was a modified version of the one proposed by JIMÉNEZ and CLÁRIA $^{(5)}$, the main difference being the gradual increase in the gassed time - by 30 seconds every three sessions - thus producing progressive disarray in the hepatic parenchyma without leading to the pronounced mortality as initially observed, when 1-minute increases in the inhalation time were employed ${ }^{(6)}$.

Lipoperoxidation is a marker for the damage to cell membranes and, in the TBA-RS method, it is measured through the formation of an intermediate compound of lipoperoxidation, malondialdehyde. The levels of this compound were quite increased in the cirrhotic group, showing a great increase in the oxidative stress as compared to the control group. This increase may be ascribed to the generation of trichloromethyl radicals $\left({ }^{\circ} \mathrm{CCl}_{3}\right)$, which combine with oxygen and form the trichloromethyl peroxyl radical $\left(\mathrm{O}_{2} \mathrm{CCl}_{3}\right)$, after carbon tetrachloride is metabolized in the $\mathrm{p}-450$ cytochrome enzymatic complex. Once formed, these compounds trigger a cascade of reactions that culminate in lipoperoxidation ${ }^{(30)}$. On the other hand, the cirrhotic group with NAC presented significantly decreased values, similar to those of the control group. This finding was also verified by SIMILE et al. ${ }^{(38)}$, using antioxidant 5'Methylthioadenosine. NAC administration seems to protect the hepatic parenchyma against the action of trichloromethyl and trichloromethyl peroxyl radicals, due to its antioxidant potential. NAC acts as an antioxidant which effectively reduces oxygen reactive species. It presents potent ability to interact directly with oxidant agents, acting as a scavenger of free radicals, and it exerts an indirect effect on the antioxidant mechanism, since it contributes to restore glutathione. This drug is defined as a precursor for the synthesis of this antioxidant enzyme ${ }^{(26)}$.

Glutathione peroxidase is a key enzyme in the antioxidant defense system, and it acts by catalyzing the transformation of hydrogen peroxide into water, being dependent on selenium and reduced glutathione ${ }^{(18)}$. This enzyme also plays a major protective role in the hepatic necrosis produced by acetaminophen ${ }^{(23)}$. It is depleted in the cirrhotic group, in the attempt to stabilize the oxygen reactive species formed by the high lipoperoxidation index observed in this group. In contrast, in the group treated with NAC, the activity levels of this enzyme were found to be similar to those of control animals. This may be accounted for by the fact that NAC serves as a substrate for glutathione, thus restoring the hepatic levels of this enzyme ${ }^{(41)}$.

On the collagen quantification, our results show a 5.6-fold elevation in the cirrhotic group as compared to the control group, while in the treated group there was a pronounced decrease (1.6-fold as compared to controls) in the levels of this build-up. This may be explained by NAC being suppressing the expression of collagen-promoting gene $\alpha_{2}{ }^{(37)}$, thus decreasing its synthesis. Another mechanism would be NAC's proven ability to partially inactivate NF- $\mathrm{KB}$, which is implied in the activation of collagen-producing stellate cells ${ }^{(35,36)}$. Another factor that may be contributing in the decreased production of collagen is the decrease in lipoperoxidation triggering the cicatricial response.

Although the relationship between increased lipoperoxidation and increased collagen synthesis has been studied, some mechanisms have not yet been completely clarified.

Several chronic liver diseases are characterized by a progressive accumulation of conjunctive tissue suffering fibrosis degeneration ${ }^{(29)}$. It is known that there is an important relationship between chronic liver damage and liver fibrosis, and that the latter is possibly represented by oxidative stress associated with activation of stellate cells ${ }^{(39)}$. When activated, stellate cells leave the quiescent state and become similar to myofibroblastic cells, which are dominant producers of the extracellular matrix ${ }^{(10,11,22)}$. Several studies have demonstrated that lipoperoxidation stimulates collagen synthesis in fibroblasts and stellate cells ${ }^{(25)}$. Specifically referring to the collagen increased levels observed in $\mathrm{CCL}_{4}$-treated animals, studies have shown the decreased activity of collagenases, something which may be implied as well in the mechanism of liver fibrosis ${ }^{(12,34)}$. The results observed in the measurement of collagen levels are corroborated by the histologic analysis, where a quite pronounced nodular delimitation is observed in cirrhotic animals and a decrease of it in the treated group.

The tests of liver integrity show greater tissue injury in the cirrhotic group and indicate that injury is reduced in the treated cirrhotic animals, which presented values close to those of the controls.

The histological examination shows that cirrhosis induction was effective among the evaluated animals. With the technique of picrosirius staining, less fibrosis was observed in the $\mathrm{CCl}_{4}+\mathrm{NAC}$ group than in the $\mathrm{CCl}_{4}$ group, suggesting protection by NAC.

Nitric oxide is a vasodilator detected in the vascular system, but it is nevertheless found in all tissues. It is synthesized from L-arginine by an enzyme, nitric oxide synthase, which possesses three isoforms: NOS-1 (nc-NOS), a constitutive isoform isolated from neuronal sources; NOS-2 (iNOS), an induced isoform that is stimulated through inflammatory cytokines such as the tumor necrosis factor and interleukins 1 and 6; and NOS-3 (eNOS), a constitutive isoform isolated from endothelial cells ${ }^{(2)}$. In cirrhotic animals, iNOS shows increased expression due to liver damage and the inflammatory mediators released as result of it. In our study we observed that genic expression of iNOS is increased in the animals of the cirrhotic group, probably as a result of the liver injury stemming from the toxic metabolites of $\mathrm{CCl}_{4}$, as already demonstrated by PAVANATO et al. ${ }^{(27)}$. In the group treated with NAC, a lesser expression of iNOS was observed, possibly due to a reduction of the inflammatory process triggered by carbon tetrachloride. This decrease is due, as remarked by PASTOR et al. ${ }^{(26)}$, to the direct and indirect antioxidant actions of NAC, inhibiting the expression/liberation of cytokines and the expression of adhesion molecules and of $\mathrm{NF} \mathrm{B}^{(4)}$ 


\section{CONCLUSION}

In conclusion, NAC seams to offer protection against hepatic fibrosis in the liver of cirrhotic rats, decreasing lipoperoxidation and iNOS expression and regenerating glutathione levels.

\section{ACKNOWLEDGMENTS}

The authors would like to thank the support of "Fundação de Amparo à Pesquisa do Rio Grande do Sul" (FAPERGS), Universidade Luterana do Brasil (ULBRA) and the Leon University, Spain.

Pereira-Filho G, Ferreira C, Schwengber A, Marroni C, Zettler C, Marroni N. Papel da N-acetilcisteína na fibrose e estresse oxidativo em ratos cirróticos. Arq Gastroenterol. 2008;45(1):156-62.

RESUMO - Racional - A cirrose é o estágio final da disfunção hepática, sendo caracterizada por fibrose difusa, que compõe a resposta principal do organismo ao dano hepático. O tetracloreto de carbono inalatório é um modelo experimental efetivo, que desencadeia a cirrose e permite obter modificações histológicas e fisiológicas similares às vistas em humanos. Objetivo - Investigar os efeitos da N-acetilcisteina (NAC) sobre a fibrose e o estresse oxidativo no fígado de ratos cirróticos, analisando as provas hepáticas, a lipoperoxidação, a atividade da enzima glutationa peroxidase, a quantificação do colágeno, a histopatologia, bem como o papel do óxido nítrico. Métodos - Os animais foram divididos em três grupos experimentais: controle $(\mathrm{CO})$; cirrótico $(\mathrm{CCl})_{4}$ e $\mathrm{CCl}_{4}+\mathrm{NAC}_{\text {. }}$ Foram avaliados a lipoperoxidação, a enzima glutationa peroxidase, a histologia hepática, a quantificação de colágeno e a expressão da óxido nítrico síntase induzível (iNOS). Resultados - O grupo cirrótico tratado com a NAC demonstrou, através da análise histológica e da quantificação de colágeno, menores graus de fibrose. Este grupo demonstrou, ainda, menos dano às membranas celulares, menor decréscimo nos níveis de glutationa peroxidase e menor expressão da iNOS quando comparado com o grupo cirrótico sem tratamento. Conclusão - A NAC parece oferecer proteção contra a fibrose hepática e o estresse oxidativo no fígado de ratos cirróticos.

DESCRITORES - Cirrose. Acetilcisteína. Fibrose. Estresse oxidativo. Tetracloreto de carbono. 


\section{REFERENCES}

1. Aruoma $\mathrm{OH}$, Halliwell B, Hoey BM. The antioxidant action of $\mathrm{N}$-acetylcysteine: its reaction with hydrogen peroxide, hydroxyl radical, superoxide, and hypochlorous acid. Free Rad Biol Med. 1989;6:593-7.

2. Barry A. The role of nitric oxide in hepatic metabolism. Nutrition. 1998;14:376-90.

3. Buege JA, Aust SD. Microsomal lipid peroxidation. Methods Enzymol. 1978;52:302-10.

4. Caglikülekci M, Pata C, Apa DD, Dirlik M, Tamer L, Yaylak F, Kanik A, Aydin S The effect of $\mathrm{N}$-acetylcysteine (NAC) on liver and renal tissue inducible nitric oxide synthase (iNOS) and tissue lipid peroxidation in obstructive jaundice stimulated by lipopolysaccharide (LPS). Pharmacol Res. 2004;49:227-38.

5. Clária J, Jiménez W. Cirrosis hepática experimental y fisiopatología de la formación de ascitis en la enfermedad hepática crónica. Gastroenterol Hepatol. 1992;15:171-82.

6. Cremonese RV, Pereira Filho AA, Magalhães R, de Mattos AA, Marroni CA, Zettle CG, Marroni NP. Cirrose experimental induzida pela inalação de tetracloreto de carbono: adaptação da técnica e avaliação da peroxidação lipídica. Arq Gastroenterol. 2001;38:40-7.

7. Cuzzocrea S, Mazzon E, Costantino G, Serraino I, De Sarro A, Caputi AP. Effects of $\mathrm{N}$-acetylcysteine in a rat model of ischemia and reperfusion injury. Cardiovasc Res. 2000;47:537-48.

8. De Vries N, De Flora S. N-acetyl-cysteine. J Cell Biochem Suppl. 1993; 17F: 270-7.

9. Flohé L, Gunzler WA. Assays of glutathione peroxidase. Methods Enzimol. $1984 ; 105: 114-21$

10. Friedman SL, Roll JF, Boyles J, Bissel DM. Hepatic lipocytes: the principal collagen producing cells of normal rat liver. Proc Natl Acad Sci. 1985;82:8681-5.

11. Friedman SL. Seminars in medicine of the Beth Israel Hospital, Boston. The cellular basis of hepatic fibrosis: mechanism and treatment strategies. N Engl J Med. 1993,328:1828-35.

12. Gasso M, Rubio M, Varela G, Cabré M, Caballeria J, Alonso E, Deulofem R, Camps J, Gimenez A, Pajares M, Parés A, Mato JM, Rodés J. Effects of S-adenosylmethionine on lipid peroxidation and liver fibrogenesis in carbon tetrachloride-induced cirrhosis. J Hepatol. 1996;25:200-5.

13. Goldim JR, Raymundo MM. Pesquisa em saúde e direitos dos animais. 2nd ed. Porto Alegre: HCPA; 1997.

14. Holdines MP. Clinical pharmacokinetics of $\mathrm{N}$-acetylcysteine. Clin Pharmacokinet 1991;20:123-34.

15. Jimenez W, Clària J, Arroyo V, Rodés J. Carbon tetrachloride induced cirrhosis in rats: a useful tool for investigating the pathogenesis of ascites in chronic liver disease. Gastroenterol Hepatol. 1992;7:90-7.

16. Laurent T, Markert M, Feihl F, Schaller MD, Perret C. Oxidant-antioxidant balance in granulocytes during ARDS. Effect of N-acetylcysteine. Chest. 1996;109:163-6.

17. Llessuy SF, Milei J, Molina H, Boveris A, Milei S. Comparison of lipid peroxidation and myocardial damaged induced by adrimycin and $4^{\prime}$ epiadramycin in mice. Tumori. 1985;71:241-9.

18. Llessuy SF. Introducción y especies activas de oxígeno in estresse oxidativo antioxidantes. Canoas: ULBRA;2002. p. 21-31.

19. Lopez-Novoa JM, Navarro V, Rodicio JL, Hernando L. Cirrhosis experimental de instauración rápida. Cronologia de aparición de las lesiones hepáticas. Patologia. 1976;9:233-40

20. Lowry OH, Rosebrough NJ, Farr AL, Randall RJ. Protein measurement with Folin phenol reagent. J Biol Chem. 1951;193:265-75.

21. Mclean EK, Mclean AE, Sutton PM. Instant cirrhosis. An improved method for producing cirrhosis of the liver in rats by simultaneous administration of carbon tetrachloride and phenobarbitone. Br J Exp Pathol. 1969;50:502-6.

22. Milani S, Herbst H, Schuppan D, Surrenti C, Riechen EO, Stein H. Cellular localization of type I, III and IV procollagen gene transcripts in normal and fibrotic human liver. Am J Pathol. 1990;137:59-70.

23. Mitchell JR, Jollow DJ, Potter WZ, Gillette JR, Brodie BB. Acetaminophen-induced hepatic necrosis. IV. Protective role of glutathione. J Pharmacol Exp Ther. 1973;187:211-7.

24. Moreira AJ, Fraga C, Alonso M, Collado PS, Zettler C, Marroni C, Marroni N, González-Gallego J. Quercetin prevents oxidative stress and NF-K $\beta$ activation in gastric mucosa of portal hypertensive rats. Biochem Pharmacol. 2004;68:1939-46.
25. Parola M, Pinzani M, Casini A, Albano E, Poli G, Gentilini A, Gentilini P, Dianzani MV. Stimulation of lipid peroxidation on 4-hydroxynonenal treatment increases procollagen alpha1(I) gene expression in human liver fat-storing cells. Biochem Biophys Res Commun. 1993;194:1044-50.

26. Pastor A, Collado PS, Almar M, González-Gallego J. Antioxidant enzyme status in biliary obstructed rats: effects of N-acetylcysteine. J Hepatol. 1997;27:363-70.

27. Pavanato A, Tuñón MJ, Sánchez-Campos S, Marroni CA, Llesuy S, González-Gallego $\mathrm{J}$, Marroni N. Effects of Quercetin on liver damage in rats with carbon tetrachlorideinduced cirrhosis. Dig Dis Sci. 2003;48:824-9.

28. Peres W, Tuñon MJ, Collado PS, Herrmann S, Marroni N, Gonzalez-Gallego JG. The flavanoid quercetin ameliorates liver damage in rats with biliary obstruction. J Hepatol. 2000;33:742-50.

29. Popper H, Kent G. Fibrosis in chronic liver diseases. Clin Gastroenterol. 1975;4:315-32.

30. Recknagel RO, Glende EA Jr, Dolak JA, Waller RL. Mechanisms of carbon tetrachloride toxicity. Pharmacol Ther. 1989;43:139-54.

31. Rhoden EL, Mauri M, Petteffi L, Béllo-Klein, Zettler CG, Rhoden CR. Protective effect of colchicine on tissue damage caused by free radicals in hepatic cirrhosis: an experimental study in rats. Arq Gastroenterol. 1997;34:91-6.

32. Rivera CA, Bradford BU, Hunt KJ, Adachi Y, Schurum LW, Koop DR, Burchardt ER, Rippe RA, Thurmam RG. Attenuation of $\mathrm{CCl}_{4}$ - induced hepatic fibrosis by $\mathrm{GsCl}_{3}$ treatment or dietary glycine. Am J Physiol Gastrointest Liver Physiol. 2001;281: G200-7.

33. Rojkind M, González E. An improved method for determining specific radioactivities of proline $14 \mathrm{C}$ and hydroxyproline $14 \mathrm{C}$ in collagen and non-collagenous proteins. Anal Biochem. 1974;57:1-7.

34. Saperstein LA, Jirtle RL, Farouk M, Thompson HJ, Chung KS, Meyers WC Transforming growth factor- $\beta 1$ and mannose 6-phosphate/insulin like growth factorII receptor expression during intrahepatic bile duct hyperplasia and biliary fibrosis in the rat. Hepatology. 1994;19:412-7.

35. Schreck R, Rieber P, Baeuerle PA. Reactive oxygen intermediates as apparently widely used messengers in the activation of NF-kappa $\beta$ transcription factor and HIV-1. EMBO J. 1991;10:2247-58

36. Schreck R, Albermann K, Baeuerle P. Nuclear factor kappaß: an oxidative stressresponsive transcription factor of eukaryotic cells (a review). Free Radic Res Commun. 1992;17:221-37.

37. Segawa M, Kayano K, Sakaguchi E, Okamoto M, Sakaida I, Okita K. Antioxidant, $\mathrm{N}$-acetyl-L-cysteine inhibits the expression of the collagen $\alpha 2$ (I) promoter in the activated human hepatic stellate cell line in the absence as well as the presence of transforming growth factor $\beta$. Hepatol Res. 2002;24:305.

38. Simile MM, Banni S, Angioni E, Carta G, De Miglio MR, Muroni MR, Calvisi DF, Carru A, Pascale RM, Feo F. 5'Methylthioadenosine administration prevents lipid peroxidation and fibrogenesis induced in rat liver by carbon tetrachloride intoxication. J Hepatol. 2001;34:386-94

39. Svegliati Baroni G, D'Ambrosio L, Ferretti G, Casini A, Di Sario A, Salzano R, Ridolfi F, Sacomanno S, Jezequel A, Benedetti A. Fibrogenic effect of oxidative stress on rat hepatic stellate cells. Hepatology. 1998;27:720-6.

40. Toledo C, Salmerón JM, Rimola A, Navasa M, Arroyo V, Llanch J, Ginés A, Ginés P, Rodés J. Spontaneous bacterial peritonitis in cirrhosis: predictive factors of infection resolution and survival in patients treated with cefotaxime. Hepatology. 1993;17:251-7.

41. Vendemiale G, Grattagliano I, Caruso ML, Serviddio G, Valentini AM, Pirrelli $\mathrm{M}$, Altomare E. Increased oxidative stress in dimethylnitrosamine-induced liver fibrosis in the rat: effect of acetylcysteine and interferon- $\alpha$. Toxicol Appl Pharmacol. 2001;175:130-9.

42. Vercelino R, Tieppo J, Dias AS, Marroni CA, Garcia E, Meurer L, Picada JN, Marroni NP. N-acetylcysteine effects on genomic instability and oxidative stress in cirrhotics rats with hepatopulmonary syndrome. Basic Clin Pharmacol Toxicol. 2008;102:370-6.

43. Zafarullah M, Li WQ, Sylvester J, Ahmad M. Molecular mechanisms of N-acetylcysteine actions. Cell Mol Life Sci. 2003;60:6-20.

Recebido em 4/6/2007. Aprovado em 8/10/2007. 